\begin{tabular}{|c|c|c|}
\hline & $\begin{array}{c}\text { Науковий вісник НЛТУ України } \\
\text { Scientific Bulletin of UNFU } \\
\text { https://nv.nltu.edu.ua }\end{array}$ & \begin{tabular}{|l|l|l} 
(c) & ISSN 1994-7836 (print) \\
BY & ISSN 2519-2477 (online)
\end{tabular} \\
\hline HAT & https://doi.org/10.36930/40290903 & $@ \bowtie$ Correspondence author \\
\hline & $\begin{array}{l}\text { Article received 06.12.2019 p. } \\
\text { Article accepted 26.12.2019p. }\end{array}$ & $\begin{array}{r}\text { Yu. I. Shalovylo } \\
\text { yulya.shalovylo@gmail.com }\end{array}$ \\
\hline & UDK 630*181.351:232.322.45 & \\
\hline
\end{tabular}

Ю. І. Шаловило

Національний лісотехнічний університет Украйни, м. Львів

\title{
БАКТЕРІАЛЬНА БІОІНОКУЛЯЦІЯ ЯК СПОСІБ ПІДВИЩЕННЯ МОРФОМЕТРИЧНИХ ПОКАЗНИКІВ ОДНОРІЧНИХ СІЯНЦІВ СОСНИ ЗВИЧАЙНОЇ
}

\begin{abstract}
За результатами дослідження встановлено, що бактеріальний штам P. abietaniphila є представником рістстимулювальних бактерій. Він проявив одну із ключових властивостей Plant Growth-Promoting Bacteria (PGPB), а саме здатність продукувати фітогормон ауксинової природи - індолілтриоцтову кислоту (ІОК) у кількості 85,06 мг на літр поживного середовища. 3'ясовано, що ця властивість бактерій сприяє розвитку системної резистентності рослин та збільшенню морфофізіологічних показників проростків після біоінокуляції. Спостерігали за збільшенням довжин кореневих систем в однорічних сіянців, що попередньо інокулювалися з бактеріальним штамом P. abietaniphila на 57,7-58,7 \%. Виявлено, що тенденція до збільшення довжини кореневої системи сіянців відобразилася на збільшенні сирої маси однорічних сіянців. Для дослідної групи, що обробляли суспензією $310^{9}$ КУО/мл, це значення становило 0,283 г, а для інокулянту з $10^{8}$ КУО/мЛ - 0,210 г, тоді як для контрольної групи сіянців - 0,117 г. Загалом вдалося встановити, що загальна довжина інокульованих сіянців 3 бактеріальним штамом P. abietaniphila у всіх варіантах дослідження зростає завдяки збільшенню довжини кореневої системи. Проте з'ясовано, що оброблення 14-добових проростків суспензією, що містила $10^{9}$ КУО/мл, спричинило збільшення довжини надземної частини однорічних сіянців на $20 \%$, порівняно з відповідним контролем. Результати наших досліджень свідчать, що бактеріальний штам P. abietaniphila потенційно покращить адаптацію сіянців сосни до природних умов середовища. Це свідчить про на перспективність використання його у практиці лісового господарства, для отримання високоякісних сіянців та саджанців сосни звичайної.
\end{abstract}

Ключові слова: бактеріальна суспензія; колонісутворювальні одиниці; індолілтриоцтова кислота; Pseudomonas abietaniphila; сіянці.

Вступ. Сосна звичайна (Pinus sylvestris L.) - це головна лісотвірна порода в лісах України. За даними Державного агентства лісових ресурсів України станом на серпень 2018 р. площа всихання насаджень у лісах сягає понад 395,4 тис. га (близько 25,3 \% від загальної площі лісових ділянок України) і щорічно збільшується на 8 тис. га. Майже половина загиблих дерев, а саме 200 тис. га - це соснові насадження (State agency, 2018).

Питання нарощування лісистості входить до пріоритетних напрямів розвитку світової лісогосподарської галузі. Тому важливим завданням Державного агентства лісових ресурсів України (центрального органу виконавчої влади у галузі лісового та мисливського господарства) $є$ отримання високоякісного садивного матеріалу хвойних дерев, зокрема сосни звичайної (Sviridova, 2019). Зі світової практики стало очевидним, що єдиним безальтернативним шляхом виходу лісового господарства із системної кризи є перехід на засади сталого розвитку. Одним 3 важливих факторів досягнення цієї мети $є$ широке застосування в лісовому господарстві здобутків агробіотехнології, що стосуються розроблення ефективних новітніх біопрепаратів для покращення живлення сіянців та застосування техніки біоінокуляції.

Аналіз літературних даних. Традиційно у сільському та лісовому господарствах використовують синте- тичні хімічні сполуки для захисту рослин, що веде до зростання кількості екологічних проблем: їх виявлено у харчовому ланцюзі, пестициди мають здатність викликати стійкість у фітопатогенних організмів, встановлена токсичність для людини, рослин, домашніх тварин та дикої природи робить їх непридатними для подальшого використання.

Тому зараз на світовому ринку є потреба у нових ефективних біопрепаратах на підставі бактеріальних штамів для сільськогосподарської і лісової галузей господарства, що є екологічно безпечні. Основою сучасних біоінокулянтів є рістстимулювальні бактерії або Plant Growth-Promoting Bacteria (PGPB) - це група корисних мікроорганізмів, що можуть перебувати у зоні ризосфери, на поверхні кореня або бути асоційованими 3 коренем, і здатні збільшувати ріст рослини та стійкість проти біотичного та абіотичного стресу (Glick, 2012; Hallmann, 1997; Kloepper, 1989; Souza, 2015). Встановлено, що є декілька механізмів або генетичних процесів, через які PGPB стимулюють ріст рослин та доступність поживних речовин, а саме шляхом біологічної фіксації атмосферного азоту, перетворення нерозчинних сполук фосфатів у розчинну форму, підвищення стресостійкості внаслідок модуляції експресії 1аміноциклопропан-1-карбоксилат деамінази, продуку-

\section{Інформація про автора:}

Шаловило Юлія Ігорівна, пров. наук. співробітник, науково-дослідна частина. Email: yulya.shalovylo@gmail.com; https://orcid.org/0000-0002-2337-2523

Цитування за ДСту: Шаловило Ю. І. Бактеріальна біоінокуляція як спосіб підвищення морфометричних показників однорічних сіянців сосни звичайної. Науковий вісник НлтУ України. 2019, т. 29, № 9. С. 22-26.

Citation APA: Shalovylo, Yu. I. (2019). Bacterial bioinoculation as a method of increasing bio-morphometric parameters of scots pine seedlings. Scientific Bulletin of UNFU, 29(9), 22-26. https://doi.org/10.36930/40290903 
вання фітогормонів та сидерофорів (Glick, 2005, 2007, 2012; Chen, 2006; Souza, 2015).

Найширшого застосування набули біопрепарати у сільському господарстві на підставі бактеріальних культур родів Pseudomonas, Azotobacter, Azospirillum, Bacillus та Klebsiella spp. (Vandana, 2018; Kloepper, 1989; Souza, 2015). Проте останніми роками бактеріальні штами цих родів, як біоконтрольні агенти, почали тестувати і в лісовому господарстві. Так, іспанські та канадські дослідники з'ясували, що бактеріальний штам Pseudomonas fluorescens S32R2, ізольований з ендоризосфери здорових дерев Pinus radiate L. в осередку ураження, інгібував ріст фунгальних патогенів Heterobasidion annosum, Armillaria mellea та Fusarium circinatum in vitro та знижував наслідки патогенного впливу у $P$. radiate L. (Mesanza et al., 2016; Iturritxa, E., 2017). Бразильські дослідники, продемонстрували, що інокуляція сіянців Pinus taeda бактеріальним штамом Bacillus subtilis збільшувала біомасу коріння і пагонів на 67,1\% і 33,1 \%, відповідно (Santos, 2018). Сербські науковці встановили, що інокуляція сінців сосни звичайної та ялини комплексною бактеріальною суспензією Azotobacter chroococcum, Bacillus megaterium, B. circulans, $B$. licheniformis, B. pumilus, B. amyloliquefaciens призвела до збільшення біомаси у сосни на $43 \%$ і ялини - на $34 \%$ (Karličić, 2016).

Проте в Україні даних про вплив інокуляції бактеріальними біопрепаратами на головні хвойні деревні породи є досить мало. У попередніх наших дослідженнях виявлено, що новим потенційним представником рістстимулювальних бактерій $є$ штам $P$. abietaniphila. Так, після трьох діб інокуляції 7-добових проростків сосни звичайної з бактеріальною суспензією P. abietaniphila, відзначено збільшення морфометричних показників проростків (результати не опубліковано). На відміну від інших бактеріальних штамів роду Pseudomonas, дослідний штам виділений 3 тканин сосни звичайної в осередку ураження та здатний рости на абетиновій та дегідроабіетиновій кислотах, які своєю чергою $\epsilon$ основною складовою частиною каніфолі хвойних, а це свідчить про тісний еволюційний взаємозв'язок між цією бактерією і сосною звичайною (Martin, 1999; Mohn, 1999).

Об'єкт дослідження - біопротекторні процеси бактерій $P$. abietaniphila, що підвищують стійкість сосни звичайної.

Предмет дослідження - методи і засоби встановлення морфометричних показників однорічних сіянців сосни звичайної після бактеріальної біоінокуляції.

Мета роботи - встановити основні рістстимулювальні властивості штаму P. abietaniphila щодо сіянців сосни звичайної.

Завдання дослідження - виявити здатність штаму $P$. abietaniphila до продукції фітогормону ауксинової природи - IОК та дослідити зміну морфометричних показників сіянців сосни звичайної після інокуляції бактеріальною суспензією цього штаму.

Наукова новизна дослідження полягає в тому, що на сьогодні у веденні лісового господарства дедалі частіше стали використовувати прийоми та методи агробіотехнології. Зокрема, великої популярності набуває застосування новітніх біопрепаратів для цінних хвойних деревних порід: сосни звичайної, ялиці білої, ялини європейської та ін. Тому актуальним є пошук нових ефек- тивних бактеріальних штамів із рістстимулювальними властивостями, що сприятимуть підвищенню імунності сіянців та саджанців сосни звичайної і стійкості до негативної дії біотичних та абіотичних чинників довкілля.

Матеріали та методи дослідження. Визначення вмісту ауксину (індолілтриоцтової кислоти (IOK)) у культуральному середовищі бактерій. Для виявлення здатності бактеріального штаму $P$. abietaniphila продукувати фітогормони ауксинової природи використали колориметричний метод за Сальковським (Gordon, 1951). Для цього бактеріальні клітини нарощували у колбах упродовж чотирьох діб у середовищі Кінга 3 додаванням 0,5\% триптофану на качалці (240 об/хв) за $30{ }^{\circ} \mathrm{C}$ упродовж 24 год. Відбирали 1,5 мл нарощеної бактеріальної суспензії у мікропробірки та осаджували центрифугуванням (13 000 об./хв, упродовж 10 хв). У підготовлені лабораторні пробірки додавали 1 мл утвореної надосадової рідини та 4 мл реактиву Сальковського (1 мл 0,5 $\mathrm{M} \mathrm{FeCl}_{3}, 50$ мл $\mathrm{H}_{2} \mathrm{O}$ і 30 мл конц. $\left.\mathrm{H}_{2} \mathrm{SO}_{4}\right)$. Наявність IОК у культуральному середовищі визначали за появою рожевого забарвлення.

Вміст досліджуваного фітогормону у культуральній рідині кількісно визначали спектрофотометрично за допомогою спектрофотометра ULAB 102 UV, за довжини хвилі 530 нм. Як контроль використали стерильне поживне середовище 3 триптофаном без бактеріальної культури. Кількість ауксину вираховували відносно калібрувальної кривої для стандартного розчину IOK (50 мг/л). Вміст ІОК у культуральному середовищі обчислювали як різницю між отриманим значенням досліджуваного зразка та контрольної групи.

Біоінокулячія проростків сосни звичайної. У дослідах використано насіння P. sylvestris L., люб'язно надане Львівським лісовим селекційно-насіннєвим центром. У чашках Петрі пророщували по 50 насінин на фільтрувальному папері, попередньо змоченому дистильованою водою, за температури $+26{ }^{\circ} \mathrm{C}$. На 14-ту добу корінці проростків сосни інокулювали бактеріальною суспензією впродовж 2 год, що містила $10^{9}$ та $10^{8}$ колоніє утворюючих одиниць у мілілітрі середовища (КУО/мл). Як контроль використали фізіологічний розчин - 0,9 \% розчин натрій хлориду. По 10 оброблених проростків сосни, для кожного варіанта дослідження, висаджували в горщики 3 поліетиленових матеріалів, що наповнювали грунтосумішшю.

Щоб оцінити дію бактеріальної інокуляції, проводили облік збереження однорічних сіянців. Вимірювали морфометричні показники сіянців сосни звичайної контрольної і дослідної групи на 45-й тиждень після інокуляції. Довжину надземної частини (англ. Shoot Length, SL), кореневої системи (англ. Root Length, RL), сумарну довжину сіянців (англ. Total Seedlings Length, TSL) вимірювали у міліметрах за допомогою лінійки. Загальну масу свіжих проростків (англ. Fresh Weight of Seedlings, FWS) визначали зважуванням на лабораторних вагах Mettler PM 4600, з точністю до сотої частини грама.

Статистичні методи дослідження. Статистичне опрацювання отриманих результатів проводили з використанням програми Microsoft EXCEL-2007. Побудову 3D моделей та обчислення статистичних даних проводили за допомогою стандартного модуля Multiple Regression програми STATISTICA 10.0. Досліди проведено у дво-триразовій повторності для кожного варіанта. 
Результати дослідження. Вплив бактерій групи PGPB на рослинний організм здебільшого досягається внаслідок продукування фітогормонів ауксинової групи. Продукування ІОК рістстимулювальними бактеріями, - це один із шляхів стимулювання проростання насіння, пришвидшення росту кореня, зміни структури кореневої системи, збільшення біомаси коріння і зрештою пришвидшення росту рослини (Datta, 2000).

Використовуючи якісну реакцію на з'єднання, що містять індол, ми перевірили вміст ауксинів у бактеріальному культуральному середовищі $P$. abietaniphila. Спостерігали за зміною забарвлення в рожевий колір у пробірці, де знаходився дослідний зразок. Утворення забарвленої сполуки ІОК з реактивом Сальковського вказує, що штам бактерій $P$. abietaniphila продукує фітогормон з ряду ауксинів (рис. 1).

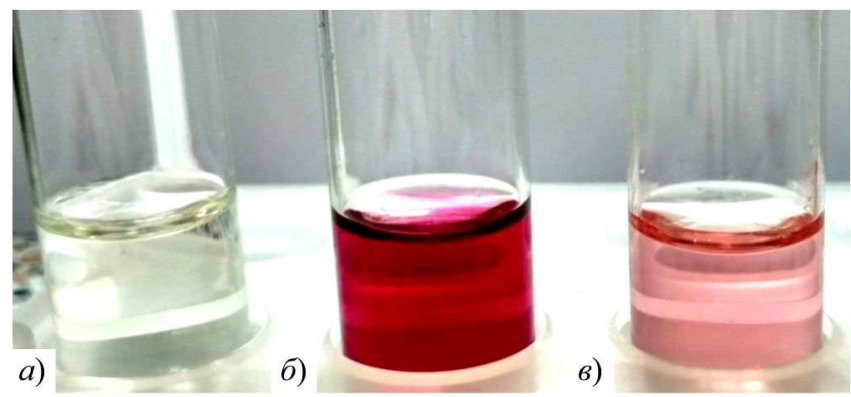

Рис. 1. Якісне виявлення ІОК у культуральному середовищі бактерій P. abietaniphila (в). Як контроль використали зразки з дистильованою водою (a) (негативний контроль) і розчином IOК з концентрацією 200 мкг/мл (б)

Використовуючи спектрофотометричний метод, детектували, що бактеріальний штам P. abietaniphila здатний синтезувати 85,06 мг ІОК на літр середовища, відповідно до значень калібрувальної кривої для ІОК. Це значення у 2,75 раза більше, відносно контролю - середовище без росту бактерій. 3 аналізу літературних даних нам вперше вдалося встановити цю властивість для штаму $P$. abietaniphila.

Здатність бактеріальних штамів до синтезу фітогормону корелює зі зростанням морфометричних показників рослин, що попередньо ними інокулюються. Наступним етапом роботи були дослідження впливу інокуляції бактеріальним штамом P. abietaniphila на проростки сосни звичайної. На час аналізу досліду, встанови- ли, що попередня обробка 14-добових проростків $P$. sylvestris L. бактеріальною суспензією, збільшує збереженість однорічних сіянців у грунтовому субстраті в 1,9-2,0 рази відносно контролю.

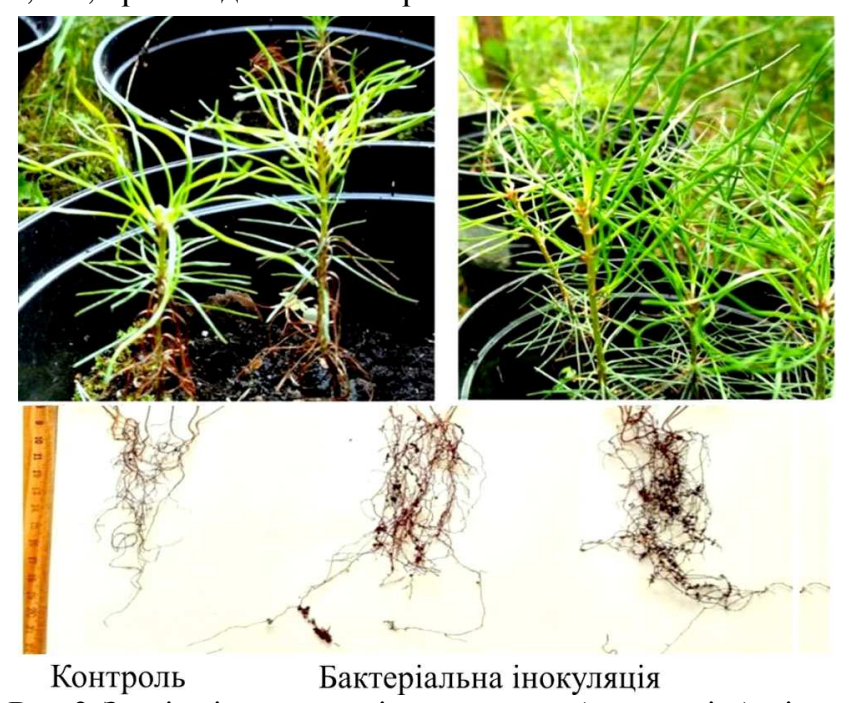

Рис. 2. Зовнішній вигляд не інокульованих (зверху зліва) й інокульованих (зверху справа) сіянців P. sylvestris L. та їх кореневих систем на 45-й тиждень після інокуляції, бактеріальними штамом P. abietaniphila

Окрім цього бактеріальна біоінокуляція позитивно впливала на біометричні показники однорічних сіянців сосни звичайної. Так, довжина кореневої системи у сіянців експериментальної групи, які інокулювали з бактеріальною суспензією, що містила $10^{9} \mathrm{KУО/мл,} \mathrm{збіль-}$ шувалася на $57,7 \%$, тоді як оброблення інокулянтом, що містив $10^{8}$ КУО/мл - на 58,7\%, відносно контрольної групи проростків (таблиця, рис. 2, знизу).

На час аналізу біометричних показників однорічних сіянців $P$. sylvestris L. виявили достовірну позитивну різницю у довжині надземної частини у варіантах з бактеріальною суспензію, що містила $10^{9}$ КУО/мл. Спостерігали тенденцію до збільшення лінійного розміру стебла на $20 \%$, порівняно з відповідним контролем (див. таблицю).

Використовуючи 3D моделі у програмі Statistica, провели порівняльний аналіз залежності загальної сирої маси однорічних сіянців сосни звичайної від довжин кореневої системи та надземної частини, за дії бактеріальної біоінокуляції штамом P. abietaniphila (рис. 3).

Таблиця. Основні статистичні показники значень біометричних показників однорічних сіянців сосни звичайної після оброблення бактеріальною суспензією P. abietaniphila

\begin{tabular}{|c|c|c|c|c|c|c|c|c|c|}
\hline & & \multirow{2}{*}{ Варіант } & \multicolumn{7}{|c|}{ Показник } \\
\hline & & & $A M$ & $\min$ & $\max$ & $s$ & $\sigma$ & $C V, \%$ & $S E$ \\
\hline \multirow{9}{*}{ 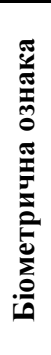 } & \multirow{3}{*}{$S L, \mathrm{~mm}$} & Контроль & 68,4 & 63 & 76 & 22,78 & 4,77 & 7,0 & 1,59 \\
\hline & & Дослід з $10^{8}$ КУО/мл & 70,8 & 60 & 83 & 62,17 & 7,88 & 11,1 & 3,22 \\
\hline & & Дослід з $10^{9} \mathrm{KУO/мл}$ & 82,6 & 75 & 95 & 31,53 & 5,61 & 6,8 & 1,87 \\
\hline & \multirow{3}{*}{$R L, \mathrm{~mm}$} & Контроль & 113,2 & 25 & 221 & 3679,44 & 60,66 & 53,6 & 20,22 \\
\hline & & Дослід з $10^{8}$ КУО/мл & 179,7 & 121 & 223 & 1799,07 & 42,42 & 23,6 & 17,32 \\
\hline & & Дослід з $10^{9}$ КУО/мл & 178,6 & 109 & 266 & 2803,78 & 52,95 & 29,7 & 17,65 \\
\hline & \multirow{3}{*}{$T W S, \mathrm{~g}$} & Контроль & 0,117 & 0,04 & 0,20 & 0,003 & 0,059 & 50,2 & 0,020 \\
\hline & & Дослід з $10^{8}$ КУО/мл & 0,210 & 0,12 & 0,36 & 0,007 & 0,081 & 38,6 & 0,033 \\
\hline & & Дослід з $10^{9}$ КУО/мл & 0,283 & 0,17 & 0,39 & 0,004 & 0,065 & 22,9 & 0,022 \\
\hline
\end{tabular}

Примітка: $S L$ - довжина надземної частини сіянця; $R L$ - довжина кореневої системи, $T W S$ - загальна маса свіжих сіянців; $A M$ - стандартне значення ознаки; $\min$ - мінімальне значення ознаки; max - максимальне значення ознаки; $s-$ дисперсія; $\sigma$ стандартне відхилення; $C V$ - коефіцієнт варіації; $S E$ - стандартна помилка середнього значення 

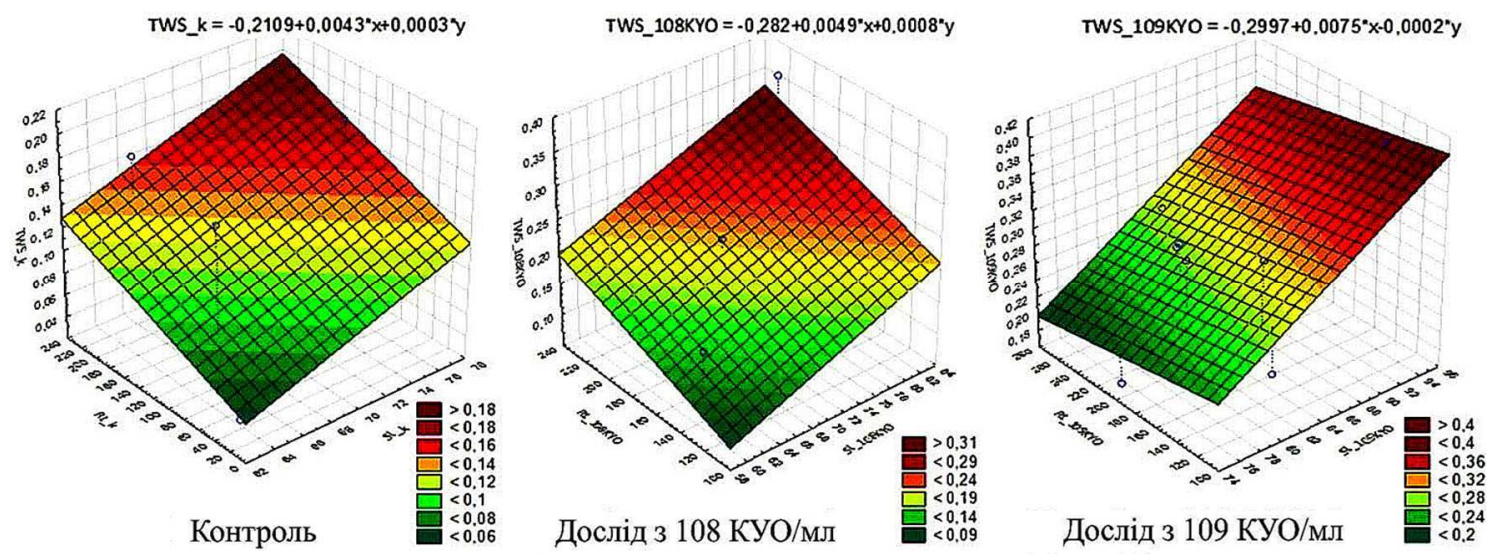

Рис. 3. 3D моделі залежностей маси однорічного сіянці від довжини надземної та кореневої систем: TSL - загальна сира маса однорічних сіянців (г); $S L$ - довжина надземної частини сіянця (мм); $R L$ - довжина кореневої системи (мм)

Визначили, що вплив бактерій з кількістю $10^{9} \mathrm{KУО}$ описується таким рівнянням: $\operatorname{TWS}\left(10^{9} \mathrm{KVO}\right)=-0,299+$ $0,0075 \cdot x-0,0002 \cdot y$, тоді як дія інокулянту, що містив $10^{8} \mathrm{KYO}-\mathrm{TWS}\left(10^{9} \mathrm{KYO}\right)=-0,282+0,0049 \cdot x-0,0008 \cdot y$. На підставі цих даних нам вдалося встановити, що здатність бактерій до синтезу фітогормону ауксинової природи веде до збільшення підземної частини сіянців сосни звичайної у всіх варіантах дослідження, відносно відповідного контролю. Проте збільшення кількості клітин в інокулянті у 10 разів спричиняє покращення росту і надземної частини на 11,8 мм та 14,2 мм відносно контрольної групи сіянців та тесту з $10^{8}$ КУО, відповідно. Тенденція до збільшення довжин кореневої системи позначилася на збільшенні сирої маси однорічних сіянців. Для дослідної групи, що обробляли суспензією $310^{9} \mathrm{KУО/мл,} \mathrm{це} \mathrm{значення} \mathrm{становило} 0,283$ г, а для інокулянту з $10^{8} \mathrm{KУО/мл} \mathrm{-} \mathrm{0,210} \mathrm{г,} \mathrm{тоді} \mathrm{як} \mathrm{для} \mathrm{контрольної}$ групи сіянців - 0,117 г. Ймовірно, бактерії штаму $P$. abietaniphila володіють й іншими рістстимулювальними властивостями, зокрема, здатні поглинати атмосферний азот та переводити нерозчинні сполуки Фосфору у легкодоступну форму для рослин. Тому збільшення клітин в інокулянті на порядок чинить ефект збільшення морфометричних показників сіянців сосни, не лише за дії фітогормону, але і завдяки покращенню їх мінерального живлення.

Обговорення результатів дослідження. Бактерії роду Pseudomonas - це одна 3 найчисленніших груп рістстимулювальних мікроорганізмів, на підставі яких розроблено сучасні біопрепарати для рослин, що здатні покращувати їх ріст та сприяти захисту від атак патогенними організмами. На підставі наших досліджень нам вперше вдалося виявити нового представника групи PGPB - P. abietaniphila. Виявлено його здатність до продукування фітогормону ауксину, подібно до інших рістстимулювальних бактерій цього роду. Таку властивість описано і для $P$. fluorescence, ізольованого зі зони ризосфери цибулі, що продукував IОК у кількості $15,38^{ \pm 0,537}$ мкг/мл середовища (Reetha, 2014). За результатами іншого дослідження встановлено, що бактеріальні штами $P$. fluorescens i $P$. putida, ізольовані з ризосфери м'якої пшениці, синтезують ІОК in vitro у кількості 89 мкг/мл та 116 мкг/мл, відповідно (Meliani, 2017).

IOК допомагає в утворенні більш довгих коренів зі збільшенням кількості кореневих волосків і бічних сторін кореня, які залучені у поглинанні поживних речовин (Datta, 2000). Тому інокуляція 14-добових проростків сосни звичайної бактеріальною суспензією $P$. abi- etaniphila сприяла кращому розвитку кореневої системи в однорічних сіянців у межах $57,7-58,7 \%$, порівняно 3 контролем. Відповідно детектували і збільшення сирої маси сіянців майже вдвічі. Проте у дослідженні з сіянцями $P$. taeda L. показано, що інокуляція з бактеріальним штамом P. fluorescens, щео продукує ауксини, веде до збільшення довжини кореня в межах стандартної похибки, але спостерігали за зменшенням біомаси кореневої системи до $31,42 \%$ (Santos, 2018). Проте у дослідженні з проростками Acacia polyphylla DC., що попередньо біоінокулювалися 3 бактеріальною суспензією $P$. fluorescens (strain MCR1.10), що синтезує 441,8 мкг/мл ІОК, встановлено достовірне збільшення кількості додаткових корінців, але зменшення загальної сухої маси іiї на 19,7 \%, порівняно з контролем (Castro, 2018).

Висновки. За результатами дослідження нам вперше вдалося встановити, що бактеріальний штам P. abietaniphila є представником рістстимулювальних бактерій, за його властивістю до синтезу фітогормону ауксинової природи - ІОК. Окрім цього цей бактеріальний штам сприяє зростанню основних морфофізіологічних показників однорічних сіянців сосни звичайної: довжини кореневої системи - на 57,7-58,7\% (під час аналізу усіх дослідних груп) та довжини стебла на 14,2 мм (після оброблення бактеріальною суспензією, що містила $10^{9} \mathrm{KУО/мл).} \mathrm{Саме} \mathrm{на} \mathrm{підставі} \mathrm{цих} \mathrm{властивостей} \mathrm{шта-}$ му P. abietaniphila та з використанням техніки біоінокуляції сіянців і сіянців сосни звичайної цією бактеріальною суспензією покращуватиметься адаптація сіянців сосни до природних умов середовища. Це свідчить про перспективність використання його в практиці лісового господарства для отримання високоякісних сіянців і саджанців сосни звичайної, а також для підвищення агрономічної ефективності завдяки зниженню собівартості та забруднення навколишнього середовища на противагу хімічним препаратам.

Публікація містить результати досліджень, проведених за грантом Президента України за конкурсним проектом Ф82/217-2019.

\section{References}

Biological fire. (2018). The area of trees drying is almost 400 thousand hectares. State Agency of Forest Resources of Ukraine. Retrieved from: https://dklg.kmu.gov.ua/forest/control/uk/publish/ article?art_id=194269\&cat_id=32888\&fbclid=IwAR1TnrfSCTNYfHkQur8bwEbh2WsQFmBERuDL6UVovG9YstHRknbzCDboh4. Castro, R. A., Dourado, M. N., Almeida, J. R., Lacava, P. T., Nave, A., Melo, I. S., \& Quecine, M. C. (2018). Mangrove endophyte promotes reforestation tree (Acacia polyphylla) growth. Brazilian jour- 
nal of microbiology: publication of the Brazilian Society for Microbiology, 49(1), 59-66. https://doi.org/10.1016/j.bjm.2017.04.002

Chen, Y. P., Rekha, P. D., Arun, A. B., Shen, F., Lai, W., \& Young, C. (2006). Phosphate solubilizing bacteria from subtropical soil and their tricalcium phosphate solubilizing abilities. Appl. Soil Ecol., 34, 33-41. https://doi.org/10.1016/j.apsoil.2005.12.002

Datta, C., \& Basu, P. (2000). Indole acetic acid production by a Rhizobium species from root nodules of a leguminous shrub Cajanus cojan. Microbiol. Res., 155, 123-127. https://doi.org/10.1016/S0944$\underline{5013(00) 80047-6}$

Glick, B. (2005). Modulation of plant ethylene levels by the bacterial enzyme ACC deaminase. FEMS Microbiol Lett., 251, 1-7. https://doi.org/10.1016/j.femsle.2005.07.030

Glick, B. (2012). Plant growth-promoting bacteria: Mechanisms and applications. Scientifica, 1-15. https://doi.org/10.6064/2012/963401

Glick, B., Cheng, Z., Czarny, J., \& Duan, J. (2007). Promotion of plant growth by ACC deaminasecontaining soil bacteria. Eur. J. of Plant Pathol., $119, \quad 329-339$. https://doi.org/10.1080/07352680701572966

Gordon, S. A., \& Weber, R. P. (1951). Colorimetric estimation of indole acetic acid. Plant Physiol., 26, 192-195. https://doi.org/10.1104/pp.26.1.192

Hallmann, J., Quadt-Hallmann, A., Mahaffee, A. W., \& Kloepper, J. W. (1997). Endophytic bacteria in agricultural crops. Can. J. Microbiol., 43, 895-914.https://doi.org/10.1139/m97-131

Iturritxa, E., Trask, T., Mesanza, N., Raposo, R., Elvira-Recuenco, M., \& Patten C. (2017). Biocontrol of Fusarium circinatum infection of young Pinus radiata trees. Forests, 8, 32. https://doi.org/10.3390/f8020032

Karličić, V., Golubović Ćurguz, V., \& Raičević, V. (2016). The alleviation of reforestation challenges by beneficial soil microorganisms. Reforesta, $1, \quad 238-260$. https://doi.org/10.21750/REFOR.1.12.12

Kloepper, J. W., Lifshitz, R., \& Zablotowicz, R. M. (1989). Free-living bacterial inocula for enhancing crop productivity. Trends Biotechnol., 7, 39-43. https://doi.org/10.1016/0167-7799(89)90057-7

Martin, V. J., Yu, Z., \& Mohn, W. W. (1999). Recent advances in understanding resin acid biodegradation: microbial diversity and metabolism. Arch. Microbiol., 172(3), 131-138. https://doi.org/10.1007/s002030050752

Meliani, A., Bensoltane, A., Benidire, L., \& Oufdou, K. (2017). Plant Growth-Promotion and IAA Secretion With Pseudomonas fluorescens and Pseudomonas putida. Research \& Reviews: Journal of Bo- tanical Sciences, 6(2), 16-24. Retrieved from: https://www.rroij. com/open-access/plant-growthpromotion-and-iaa-secretion-

withpseudomonas-fluorescens-and-pseudomonas-putida-.pdf

Mesanza, N., Iturritxa, E., \& Patten, C. L. (2016). Native rhizobacteria as biocontrol agents of Heterobasidion annosum s.s. and Armillaria mellea infection of Pinus radiata. Biol. Control., 101, 8-16. https://doi.org/10.1016/j.biocontrol.2016.06.003

Mohn, W., Wilson, A., Bicho, P., \& Moore, E. (1999). Physiological and phylogenetic diversity of bacteria growing on resin acids. Syst. Appl. Microbiol., 22(1), 68-78. https://doi.org/10.1016/S0723$\underline{\text { 2020(99)80029-0 }}$

Moraga-Suazo, P., \& Sanfuentes, E. (2017). Growth promotion of Pinus radiata seedlings by soil inoculation and seed pretreatment with the biological control agent Clonostachys rosea. Gayana Bot., 74(1), 140-146. $\quad$ https://doi.org/10.4067/S0717$\underline{66432017005000106}$

Patten, C. L., \& Glick, B. R. (2002). The role of bacterial indoleacetic acid in the development of the host plant root system. Appl. Environ. Microbiol., $\quad 68, \quad 3795-3801$. https://doi.org/10.1128/AEM.68.8.3795-3801.2002

Reetha, S., Bhuvaneswari, G., Thamizhiniyan, P., \& Ravi Mycin, T. (2014). Isolation of indole acetic acid (IAA) producing rhizobacteria of Pseudomonas fluorescens and Bacillus subtilis and enhance growth of onion (Allim cepa. L). Int. J. Curr. Microbiol. App. Sci., 3(2), 568-574. Retrieved from: https://www.ijcmas.com/vol-3-2/S. Reetha, \%20et\%20al.pdf

Santos, R., Cruz, S., Botelho, G., \& Flores, A. (2018). Inoculation of Pinus taeda Seedlings with Plant Growth-promoting Rhizobacteria. Floresta Ambient., 25(1), e20160056. https://doi.org/10.1590/2179$\underline{8087.005616}$

Souza, R., Ambrosini, A., \& Passaglia, M. (2015). Plant growth-promoting bacteria as inoculants in agricultural soils. Genetics and Molecular Biology, 38(4), 401-419. https://doi.org/10.1590/S1415475738420150053

Sviridova, S. S. (2019). Ukrainian forestry building strategy of increase of potential of ukrainian forestry. Black sea economic studies, 41, 121-125. Retrieved from: https://nbuv.gov.ua/UJRN/bses_2019_41_24

Vandana, U. K., Chopra, A., Choudhury, A., Adapa, D., \& Mazumder, P. B. (2018). Genetic diversity and antagonistic activity of plant growth promoting bacteria, isolated from tea-rhizosphere: a culture dependent study. Biomedical Research, 29(4), 853-864. https://doi.org/10.4066/biomedicalresearch.29-18-428

Yu. I. Shalovylo

Ukrainian National Forestry University, Lviv, Ukraine

\section{BACTERIAL BIOINOCULATION AS A METHOD OF INCREASING BIO-MORPHOMETRIC PARAMETERS OF SCOTS PINE SEEDLINGS}

Plant Growth-Promoting Bacteria (PGPB) is a group of beneficial microorganisms that can be located in the rhizosphere, on the root surface or be associated with the root, and can increase plant growth and resistance to biotic and abiotic stress. The bacterial strains with plant-growth promotion activities are used in agriculture as the biofertilizers. In this study, we establish for the first time that the bacterial strain P. abietaniphila is a new candidate of PGPB. It exhibited one of the key properties of PGPB, namely, it is capable of producing phytohormone of auxins of nature - indolyl triacetic acid (IAA) in the amount of $85.06 \mathrm{mg}$ per liter of nutrient medium. This property of bacteria contributes to the development of systemic resistance of plants and increases the morphophysiological parameters of seedlings after bioinoculation with this strain. An increase in root lengths in one-year old seedlings by $57.7-58.7 \%$ was observed after pre-inoculated with the bacterial strain P. abietaniphila. The tendency of increasing the length of the root system of seedlings was reflected in the increase in the total fresh weight of one-year old seedlings. For the seedlings treated with bacterial suspension with concentrations $10^{9} \mathrm{CFU} / \mathrm{ml}$ this value was $0.283 \mathrm{~g}$, after pre-inoculation with suspension containing $10^{8} \mathrm{CFU} / \mathrm{ml}-0.210 \mathrm{~g}$, whereas for the control group weight of seedlings was $0.117 \mathrm{~g}$. In general, it was possible to establish that the total length seedlings after inoculation with the bacterial strain $P$. abietaniphila in all variants were increasing due to the increase of root length. However, bacterial treatment of 14-day-old seedlings with a suspension containing $109 \mathrm{CFU} / \mathrm{ml}$ causes increase of shoot length of seedlings up to $20 \%$, compared with control. The results of our studies indicate that the bacterial strain of $P$. abietaniphila have plant growth promoting activities. The bacterial pre-treatment of Scots pine seedlings can potentially improve their adaptation to environmental conditions. This indicates the prospect of using it in forestry practice, to produce high quality seedlings of Scots pine.

Keywords: bacterial suspension; colony forming units; indolyltrioacetic acid; Pseudomonas abietaniphila; seedlings. 